\title{
Chapter 2 \\ Some Characteristics of the Bluefin \\ Tuna. Its Geographical Distribution, Areas and Fishing Systems
}

\begin{abstract}
Some characteristics of bluefin tuna are described relating to its biology (growth, reproduction, migrations and ethology), physiology, geographical distribution and fishing. Regarding the latter, the evolution of bluefin tuna fisheries over the last seven decades is analyzed, with descriptions of the various fleets working in different regions over this period.
\end{abstract}

The Atlantic bluefin tuna belongs to the family of the Scombrid fishes (Scombridae) (Collette and Nauen 1985). It can weigh over $725 \mathrm{~kg}$ (Crane 1936; Lebedeff 1936; Heldt 1938), reach lengths of $3.3 \mathrm{~m}$ (Cort et al. 2013) and live over thirty years (Neilson and Campana 2008). In general, during its fattening phase in the first year of life it reaches $53 \mathrm{~cm}(4 \mathrm{~kg})$; at age 10, $204 \mathrm{~cm}(170 \mathrm{~kg})$; at 20 years, $273 \mathrm{~cm}(410 \mathrm{~kg})$; and at 30 years, $301 \mathrm{~cm}(550 \mathrm{~kg})$. The official record of the largest ABFT captured in the western Atlantic is $679 \mathrm{~kg}$, a fish caught in Nova Scotia waters (Canada) in 1979 (Fraser 2008). This catch also stands as the current Guinness world record. It forms large shoals and feeds mainly on other fishes, cephalopods, small crustaceans such as krill (Euphausiacea) and pelagic crabs, Polybius henslowii (Leach), (Estrada et al. 2005; Sarà and Sarà 2007; Logan et al. 2010). Its shape is highly hydrodynamic, as it is entirely adapted to mobility.

ABFT inhabits temperate waters of the North Atlantic and Mediterranean Sea (ICCAT 2010). It is found in the eastern Atlantic from Senegal (Ngon Sow and Ndaw 2010) and Cabo Verde $\left(15^{\circ} \mathrm{N}\right)$, the Mediterranean and Black Sea (Zaitsev 2003), almost as far as the Arctic Circle $\left(75^{\circ} \mathrm{N}\right)$ where temperatures of $5^{\circ} \mathrm{C}$ are recorded (De Metrio et al. 2002; MacKenzie and Myers 2007; Di Natale 2012a), and in the western part from Brazil (Takeuchi et al. 1999, 2009) to Newfoundland (Hurley and Iles 1980). It is also found in the southern Atlantic (Di Natale et al. 2013).

Its bloodstream forms the core of a highly evolved heat exchange system, and so its internal temperature can be maintained at up to $21^{\circ} \mathrm{C}$ higher than that of the water surrounding it (Carey et al. 1969; Carey and Lawson 1973). This is one of the reasons for its wide distribution in the ocean. ABFT can appear in the warm waters of the Bahamas at close to $30^{\circ} \mathrm{C}$ (Rivas 1954) and 50 days later in Norwegian waters, where the temperature hardly rises above $10^{\circ} \mathrm{C}$ (Mather III 1962). 
ABFT migrations depend on the age and length of fishes and are mainly related to spawning and the search for food. This behavioural change confirms the theory of the Norwegian scientist J. Hamre (cited by Tiews 1963), which states that ABFT behaviour changes with age, as was eventually shown years later (Lutcavage et al. 2013).

Migrations of adult fishes (fishes $>40 \mathrm{~kg}$ ) towards spawning areas in the Mediterranean and their return to the ocean for feeding have been known for thousands of years. Today thanks to electronic tagging (Tensek et al. 2018) great advances have been made on this important facet of its biology. Its migrations get longer as its size increases. In order to spawn the tunas emigrate in great shoals (Arena 1979) that choose the most appropriate areas depending on numerous ecological and environmental variables (Alemany et al. 2010).

In general, ABFT migrations, both in adults and juveniles, appear to be associated with large oceanic current systems (Fig. 2.1). Mather III et al. (1995) presented the results of diverse recoveries of large spawning tunas tagged in the Bahamas and recovered a few weeks later in Norwegian waters, which fits this theory as they appear to have followed the Gulf Stream to the north.

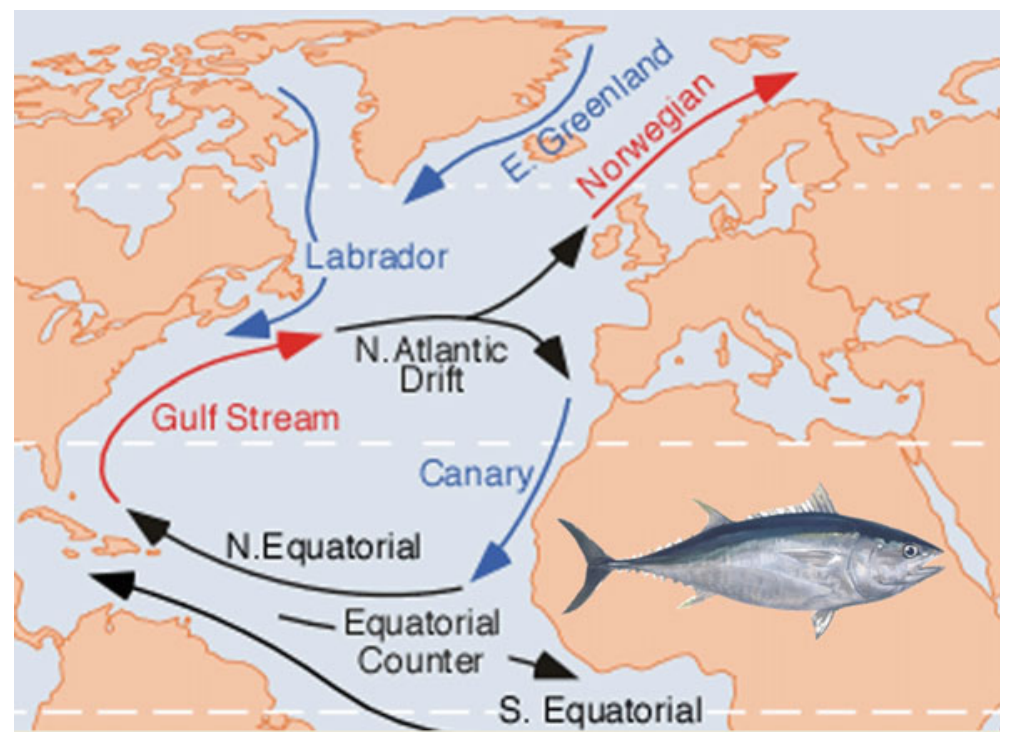

Fig. 2.1 Distribution of marine currents. https://commons.wikimedia.org/wiki/File:Corrientesoceanicas.png. Red arrows: warm currents; Blue arrows: cold currents; Black arrows: general surface currents 


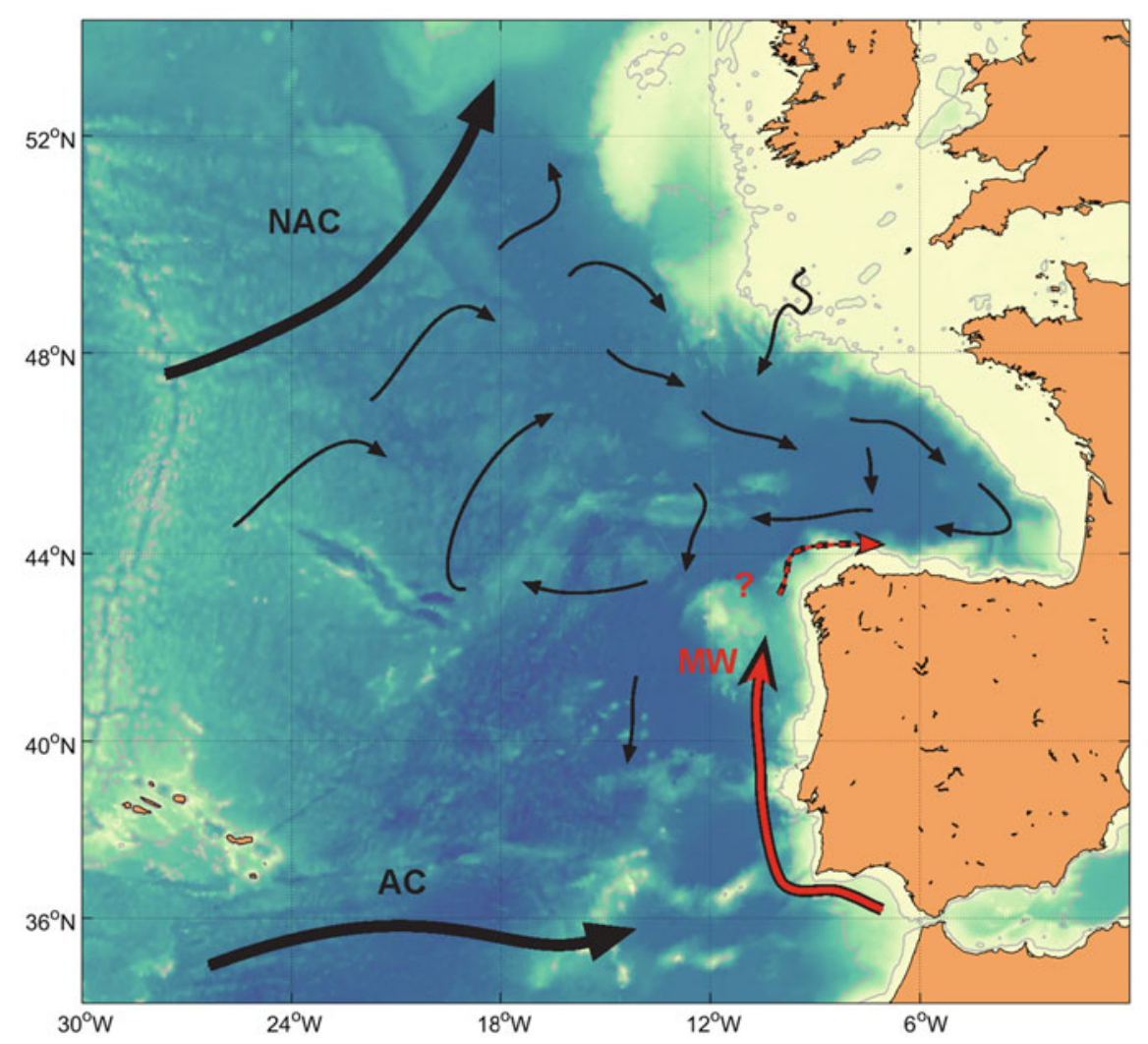

Fig. 2.2 Distribution of currents in the Northeast Atlantic. NAC North Atlantic current; AC Azores current; $M W$ Mediterranean water

There are also juvenile fishes tagged off the eastern coasts of the U.S.A. whose transatlantic migrations from the western to the eastern Atlantic (Mather III et al. 1967) can be related to the North Atlantic Current (NAC), Fig. 2.2; adapted from González-Pola et al. (2005).

Rodríguez-Roda (1967) determined the age at which they reach the first spawn and the age of absolute fecundity. According to this author, ABFT reach full maturity at 5 years of age $(130 \mathrm{~cm}, 50 \mathrm{~kg})$, the age at which a female lays 5 million eggs. At 13 years $(230 \mathrm{~cm}, 250 \mathrm{~kg})$ it lays 30 million eggs. Before him, however, other Portuguese and Italian scientists had established the first sexual maturity at age 3 years and full sexual maturity at age 4 (Frade 1935; Sarà 1961; Scaccini 1965). These data have been confirmed by other authors for the Mediterranean (Piccinetti et al. 2013).

In the West Atlantic there are two spawning areas, one in the Gulf of Mexico (Richards 1977; Mather et al. 1995; Rooker et al. 2007; ICCAT 2010) and another in the Slope Sea (Northwest Atlantic) according to Richardson et al. (2016). Spawning extends from May to early June in the Gulf of Mexico and between June and August 
in the Slope Sea. In the western and central Mediterranean Sea the spawning period runs from May to early July (Tiews 1963; Corriero et al. 2005; García et al. 2005; Medina et al. 2002) and from May to early June in the Levantine Sea according to Karakulak et al. (2004). Other possible spawning areas have been cited in the Ibero-Moroccan Bay (Rodríguez-Roda 1969; Di Natale et al. 2017).

The trophic migrations of spawners begin once the spawning period has finished and many of these ABFT return to the Atlantic Ocean (Rodríguez-Roda 1964; Tensek et al. 2018). After crossing the Strait of Gibraltar, the shoals disperse and fishes head both north and south between June and December (De Metrio et al. 2002; Aranda et al. 2013). In the 1960s North American scientists (Mather III 1962) found evidence of 'direct' transatlantic migrations of large spawning bluefin tunas tagged in Bahamas (June) that were recovered in Norwegian waters 50 days after, indicating a migration of $7800 \mathrm{~km}(155 \mathrm{~km} /$ day $)$.

The migrations of juvenile fishes $(<40 \mathrm{~kg})$ are generally shorter than those of larger fishes, though they also make transatlantic migrations in both directions. The first scientists to demonstrate this were North Americans in the 1960s, when they recaptured ABFT in the Bay of Biscay that had been tagged off the eastern coast of the U.S.A. years earlier (Mather III et al. 1967). Soon afterwards French and Spanish scientists showed that this migration also occurred in the opposite direction (Aloncle 1973; Cort 1990). In recent years, in projects financed by ICCAT-GBYP, other specimens tagged in the Bay of Biscay migrated across the Atlantic (Tensek et al. 2018). Recent studies on the chemical composition of otoliths have shown that transatlantic migrations of ABFT juveniles take place in some years in very significant numbers (Rooker et al. 2014).

ABFT frequent surface waters both in the spawning and trophic seasons (Fig. 2.3). Electronic tagging studies also reveal that they often dive to great depths, sometimes to over $800 \mathrm{~m}$ (Block et al. 2005).

The evolution of bluefin tuna fishing in the north Atlantic has gone through different phases over the last seven decades (Fig. 2.4). In this figure it can be seen how fishing for this species has changed since 1950, the first year of the ICCAT data base. It can be seen how in the 1950s they were mainly caught in the eastern Atlantic with TR (Cort et al. 2012; Pereira 2012), PS (Hamre 1960; Tangen 2009) and BB (Le Gall 1951; Cort 1990), and in the Mediterranean with TR (Di Natale 2012b) and PS (Piccinetti 1980); in the western Atlantic there were catches with TR (Dean et al. 2012), recreational, small nets and harpoon (Hurley and Iles 1980). The most remarkable in the 1960s was the development of the Japanese LL, which stretched as far as the southern hemisphere off Brazil (Takeuchi et al. 2009) and also PS in western fisheries (Sakagawa 1975; Porch 2005). In the 1970s fishing using TR diminished in the Strait of Gibraltar (Rodríguez-Roda 1977) and in the Mediterranean (ICCAT 2010), whereas the use of PS fell in the north of Europe (Nøttestad et al. 2009). In the same decade PS (Farrugio 1980) and LL (Rey 1980) developed in the Mediterranean. 


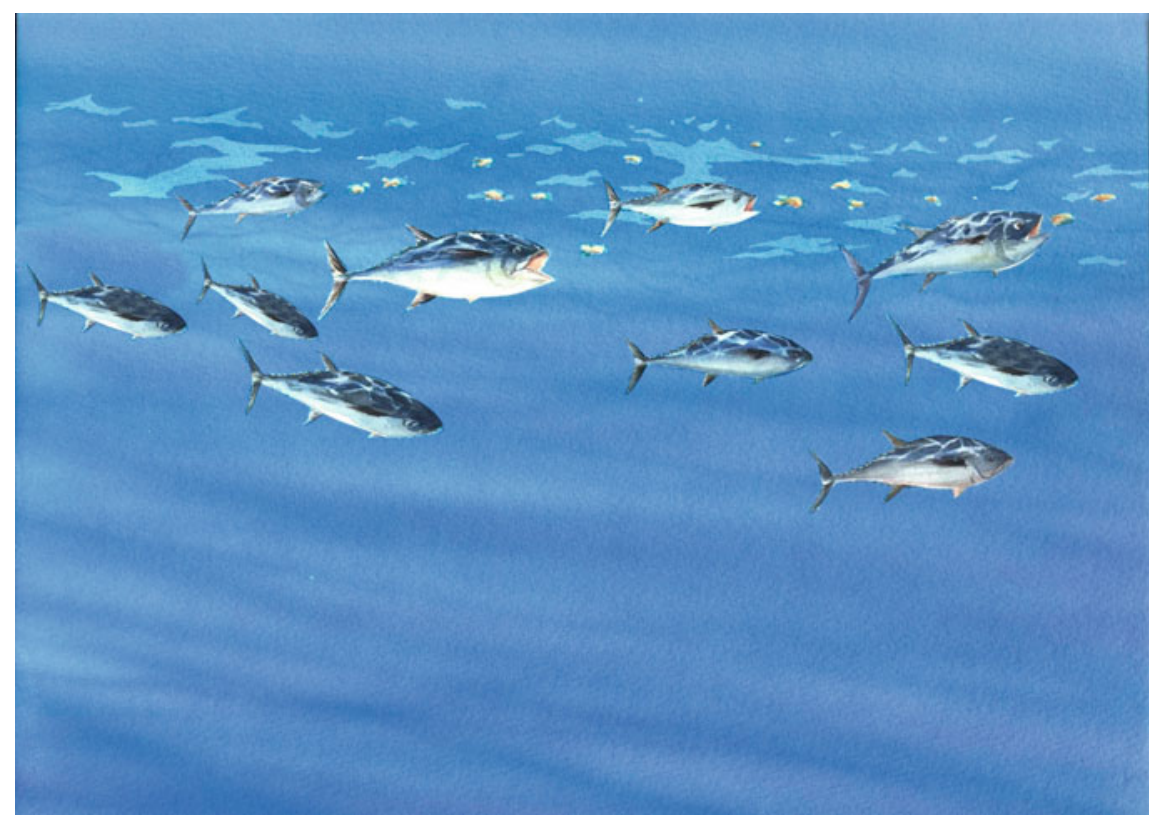

Fig. 2.3 Bluefin tuna in trophic migration Artist: Lineke Zubieta (Santander, Spain) (Documentary archive, IEO)

In the 1980s PS disappeared in the north of Europe (Nøttestad et al. 2009) while it continued to proliferate in the Mediterranean (Farrugio 1980; Arena 1982, 1988). From the 1990s the use of PS continued to increase in the western Mediterranean (Liorzou and Bigot 1993; De la Serna and Platonenko 1996) and eastern Mediterranean (Libya and Turkey) according to ICCAT (2010) and Karakulak (2003). Japanese longline also increased in the central and eastern Atlantic (Kimoto and Itoh 2017). These modern systems took over in the last century to become the most commonly used gears (ICCAT 1980). In more recent years (2000s) the greatest fishing effort is exerted in the Mediterranean (Fig. 2.5), where purse seine is used to catch fishes for fattening farms (Deguara et al. 2010; Galaz 2012; Hattour and Kouched 2013; Gordoa 2014, 2017), though in the Strait of Gibraltar fishing with traps continues (De la Serna et al. 2012; Santos et al. 2016).

Figure 2.6 shows the panorama of ABFT fishing in the middle of the 20th century when the fisheries, which had renewed their activities following the Second World War, were at their height, as was the case of the northern European fisheries and a little 

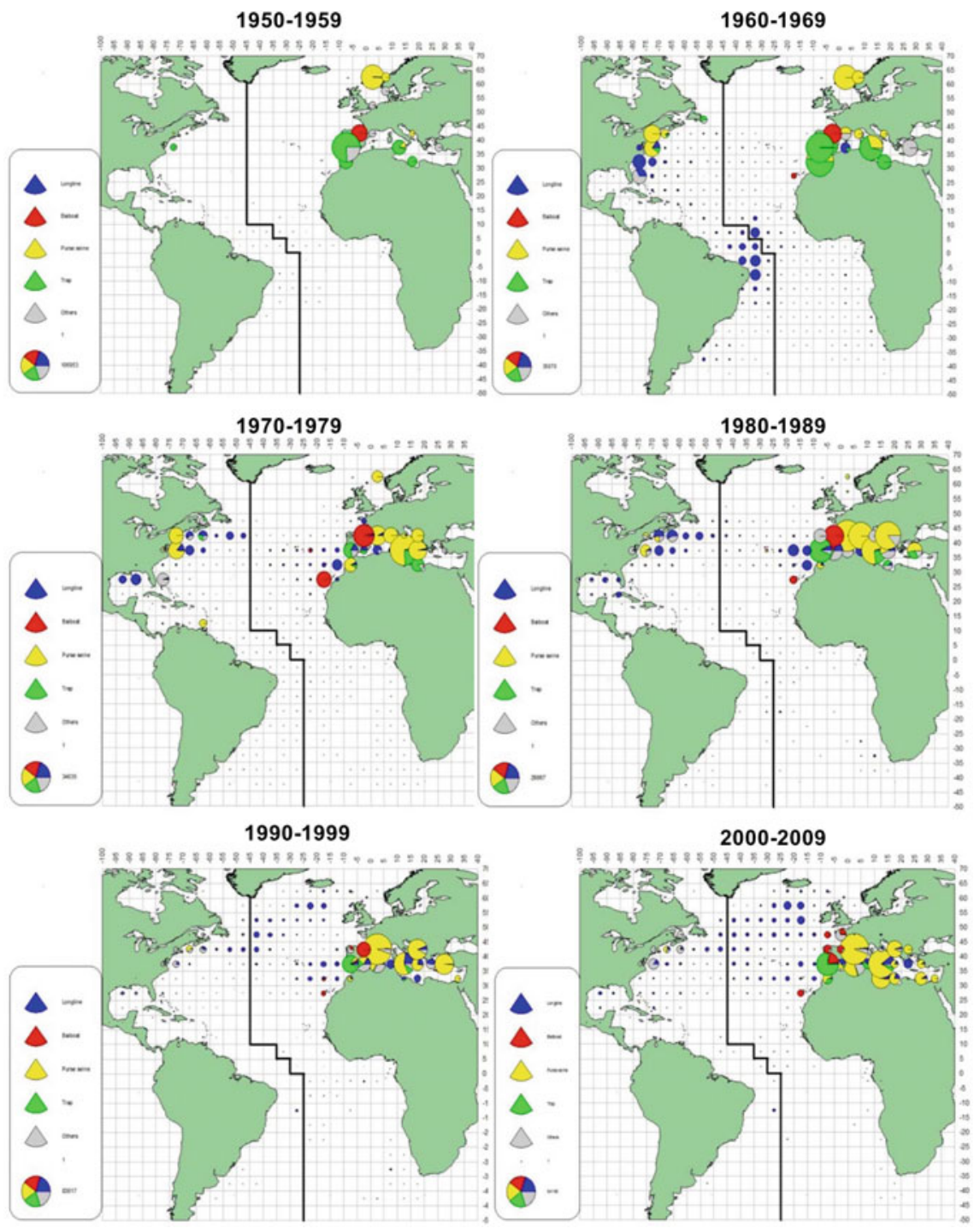

Fig. 2.4 Distribution of bluefin tuna fishing by decade [Blue, longline (LL); Red, baitboat (BB); Yellow, purse seine (PS); Green, trap (TR); Grey, others] (Courtesy of ICCAT) 


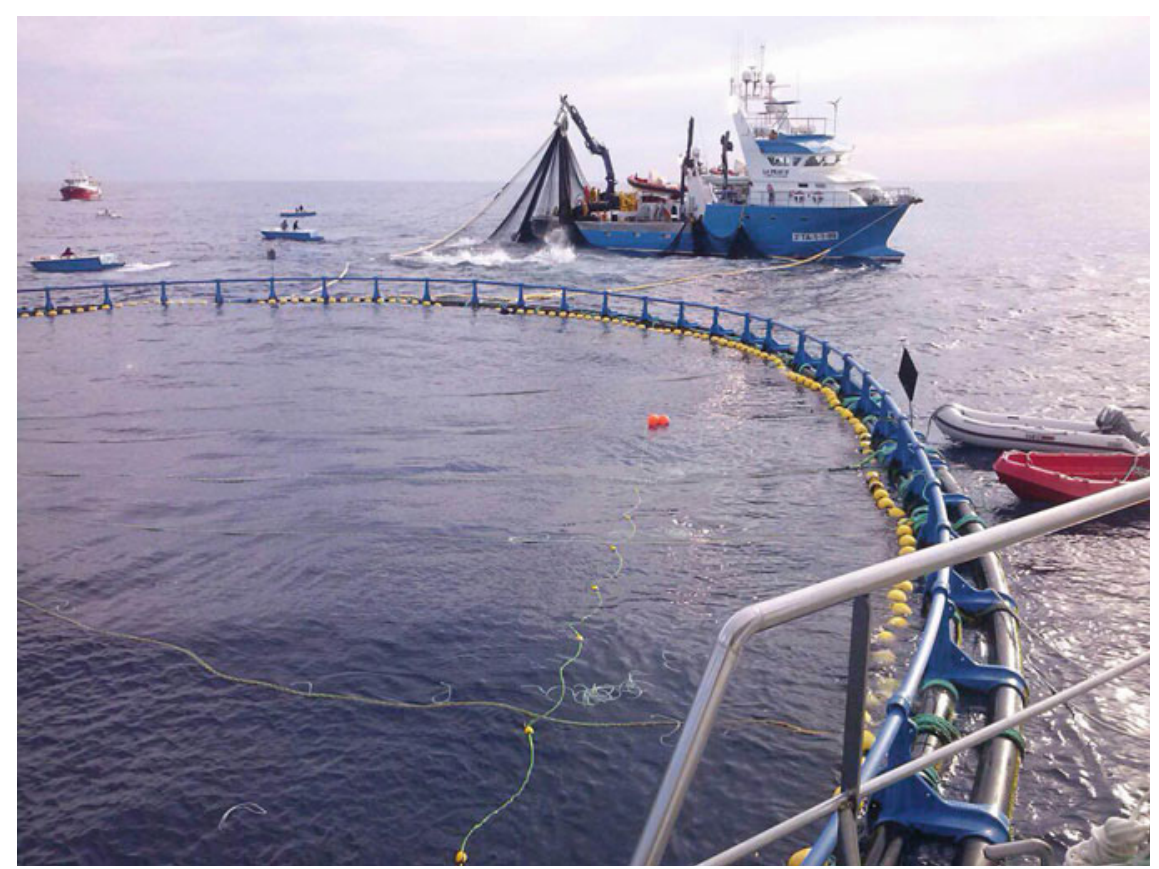

Fig. 2.5 Modern Spanish purse seiner in the western Mediterranean (Courtesy of Grup Balfegó)

later the Asian longline fisheries, mainly Japan. Also included are the purse seine fleets of the Mediterranean, whose rapid development began in the 1960s (Piccinetti 1980). The figure provides a vision of ABFT fishing when it was at its height and also its subsequent decline, using red circles to represent the fisheries that abandoned their activities following the overfishing of the 1960s in the eastern part of the Atlantic and Mediterranean, and in the 1970s in the western part of the Atlantic Ocean. 


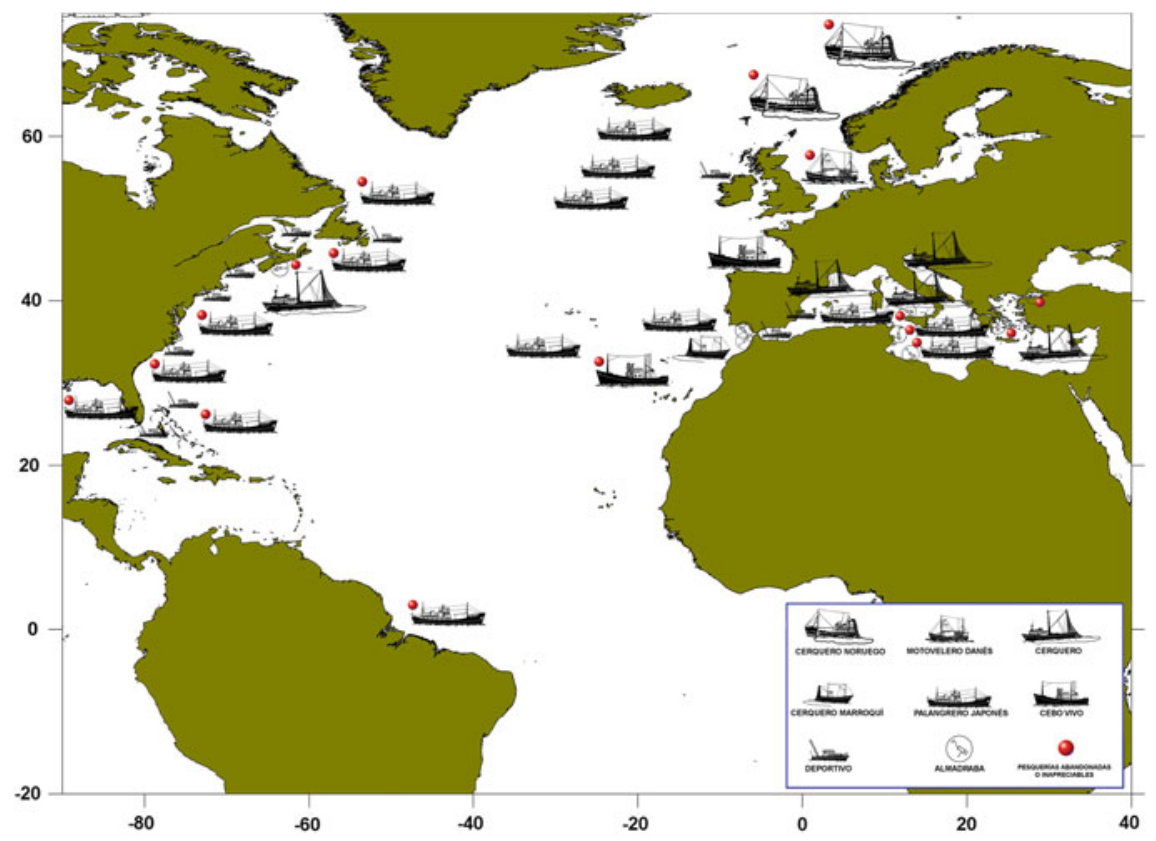

Fig. 2.6 Fleets both present and past targeting bluefin tuna. Small artisanal fisheries are not included (explanation in the text). Legend: Cerquero noruego = Norwegian purse seiner; Motovelero danés $=$ Danish motorsailer; Cerquero $=$ Purse seiner; Cerquero marroquí $=$ Moroccan purse seiner; Palangrero japonés $=$ Japanese long liner; Cebo vivo = Bait boat; Deportivo $=$ Sportive; Almadraba $=$ Tuna trap; Red bullet $=$ Abandoned or almost unworkable fisheries

\section{References}

Alemany F, Quintanilla L, Vélez-Belchí P, García A, Cortés D, Rodríguez JM et al (2010) Characterization of the spawning habitat of Atlantic bluefin tuna and related species Balearic Sea (western Mediterranean) Prog Ocean 86:21-38

Aloncle H (1973) Marquage de thons dans le Golfe de Gascogne. Col Vol Sci Pap ICCAT 1:445-458

Aranda G, Abascal FJ, Varela JL, Medina A (2013) Spawning behaviour and post-spawning migration patterns of Atlantic Bluefin tuna (Thunnus thynnus) ascertained from satellite archival tags. PLoS ONE 8(10):e76445. https://doi.org/10.1371/journal.pone.0076445

Arena P (1979) Aspects biologiques et comportement des concentrations génétiques du thon rouge en Mediterranée. Actes Colloq CNEXO 8:53-57

Arena $\mathrm{P}$ (1982) La pêche à la senne tournante du thon rouge (Thunnus thynnus L.) dans les bassins maritimes occidentaux italiens. Col Vol Sci Pap ICCAT 17(2):281-292

Arena P (1988) Rilevazini e studi sulle affluenze del tonno nel Tirreno e sull'andamento della pesca da parte delle "tonnare volanti" nel quadriennio 1984-1988. E.S.P.I. Ente Siciliano per la Promozione Industriale-Palermo Unità Operativa n. 5, 66 p

Block BA, Teo SLH, Walli A, Boustany A, Stikesbury MJW, Farwell CJ, Weng KC, Dewar H, Williams TD (2005) Electronic tagging and population structure of Atlantic bluefin tuna. Nature 434:1121-1127

Carey F, Teal JM (1969) Regulation of body temperature by the bluefn tuna. Comp Biochem Physiol 28:205-213 
Carey FG, Lawson KD (1973) Temperature regulation in free-swimming bluefin tuna. Comp Biochem Physiol 44:275-292

Collette BB, Nauen CE (1985) FAO species catalogue. Vol. 2, Scombrids of the world. An annotated and illustrated catalogue of Tunas, Mackerels, Bonitos and Related Species Known to Date. FAO Fisheries Synopsis No 125. Vol. 2-Mit 81 figs., 137 pp. Rome: FAO 1983. ISBN-Nr. 92-5-101381-0

Corriero A, Kakakulak S, Santamaría N, Deflorio M, Spedicato D, Addis P, Fenech-Farrugia A, Vassallo-Agius R, de la Serna JM, Oray I, Cau A, De Metrio G (2005) Size and age at sexual maturity of female bluefin tuna (Thunnus thynnus L. 1758) from the Mediterranean Sea. J Appl Ichthyol 21:483-486

Cort JL (1990) Biología y pesca del atún rojo, Thunnus thynnus (L.), del mar Cantábrico. Publicaciones especiales, IEO 4:272 p

Cort JL, de la Serna JM, Velasco M (2012) El peso medio del atún rojo (Thunnus thynnus) capturado por las almadrabas del sur de España entre 1914-2010. Col Vol Sci Pap ICCAT 67:231-241

Cort JL, Deguara S, Galaz T, Mèlich B, Artetxe I, Arregi I et al (2013) Determination of $L_{\max }$ for Atlantic Bluefin Tuna, Thunnus thynnus (L.), from meta-analysis of published and available biometric data. Rev Fish Sci 21(2):181-212 https://doi.org/10.1080/10641262.2013.793284

Crane J (1936) Notes on the biology and ecology of giant tunas, Thunnus thynnus Linnaeus, observed at Portland. Maine Zool 21(16):207-212

Dean JM, Andrushchenko I, Neilson JD (2012) The western Atlantic bluefin tuna trap fishery. Col Vol Sci Pap ICCAT 67:309-321

Deguara S, Caruana S, Agius C (2010) An appraisal of the use of length-weight relationships to determine growth in fattened Atlantic bluefin tuna, Thunnus thynnus. Col Vol Sci Pap ICCAT 65:776-781

De la Serna JM, Platonenko S, Alot E (1996) Observaciones preliminares sobre las capturas de atún rojo (Thunnus thynnus) con artes de cerco en el Mediterráneo occidental. Col Vol Sci Pap ICCAT 45(2):117-122

De la Serna JM, Macías D, Ortiz de Urbina JM, Rodríguez-Marín E, Abascal F (2012) Study on eastern Atlantic and Mediterranean Bluefin tuna stocks using Spanish traps as scientific observatories. Col Vol Sci Pap ICCAT 67:331-343

De Metrio G, Arnold GP, Block BA, de la Serna JM, Deflorio M, Cataldo M, Yannopoulos C, Megalofonou P, Beeper S, Farwell C, Seitz A (2002) Behaviour of post-spawning Atlantic Bluefin tuna tagged with pop-up satellite tags in the Mediterranean and eastern Atlantic. Col Vol Sci Pap ICCAT 54(2):415-424

Di Natale A (2012a) New data on the historical distribution of bluefin tuna (Thunnus thynnus, L.) in the Artic Ocean. Col Vol Sci Pap ICCAT 68(1):102-114

Di Natale A (2012b) Literature on eastern Atlantic and Mediterranean tuna trap fishery. Col Vol Sci Pap ICCAT 67:175-220

Di Natale A, Idrissi M, Justel Rubio A (2013) The mistery of bluefin tuna (Thunnus thynnus) presence and behavior in Central-South Atlantic in recent years. Col Vol Sci Pap ICCAT 69(2):857-868

Di Natale A, Tensek S, Pagá García A (2017) ICCAT Atlantic-wide research programme for bluefin tuna (GBYP): activity report for the last part of phase 5 and first part of phase 6 (2015-2016). Col Vol Sci Pap ICCAT 73(7):2424-2503

Estrada JA, Lutcavage M, Thorrold SR (2005) Diet and trophic position of Atlantic bluefin tuna (Thunnus thynnus) inferred from stable carbon and nitrogen isotope analysis. Mar Biol 147:37-45. https://doi.org/10.1007/s00227-004-1541-1

Farrugio H (1980) Bluefin fishing in the French area of the Mediterranean. Development and characteristics. Col Vol Sci Pap ICCAT 11:98-117

Frade F (1935) Recherches sur la maturité sexuelle du Thon rouge. C R Congr Int Zool 12

Fraser K (2008) Possessed: World record holder for bluefin tuna. Kingstown, Nova Scotia: T \& S Office Essentials and printing, $243 \mathrm{p}$ 
Galaz T (2012) Eleven years-1995-2005 - of experience on growth of bluefin tuna (Thunnus thynnus) in farms. Col Vol Sci Pap ICCAT 68(1):163-175

García A, Alemany F, de la Serna JM, Oray I, Karakulak S, Rollandi L, Arigo A, Mazzola S (2005) Preliminary results of the 2004 bluefin tuna larval surveys off different Mediterranean sites (Balearic Archipelago, Levantine Sea, and the Sicilian Channel). Col Vol Sci Pap ICCAT 58:1420-1428

González-Pola C, Lavín A, Vargas-Yáñez M (2005) Intense warming and salinity modification of intermediate water masses in the southeastern corner of the Bay of Biscay for the period 1992-2003. J Geophys Res 110:C05020. https://doi.org/10.1029/2004jc002367

Gordoa A (2014) Catch rates and catch size structure of the Balfegó purse seine fleet in Balearic waters from 2000 to 2014; two years of size frequency distribution based on video techniques. Col Vol Sci Pap ICCAT 71(4):1803-1812

Gordoa A (2017) Updated bluefin tuna CPUE and catch structure from Balfegó purse seine fleet in Balearic waters from 2000 to 2016. Col Vol Sci Pap ICCAT 73(6):2020-2025

Hamre J (1960) Tuna investigation in Norwegian coastal waters 1954-1958. Ann Biol Cons Int Expl Mer 15:197-211

Hattour A, Kouched W (2013) (Temporal distribution of size and weight of fattened bluefin tuna (Thunnus thynnus L.) from Tunisian farms (2005-2010). Mediterranean Marine Science. (2013). http://www.medit-mar-sc.net, http://dx.doi.org/10.12681/mm.513

Heldt H (1938) Le thon rouge et sa pêche 10 Rapp. Comm Internat Explor Medit 11:311-358

Hurley PCF, Iles TD (1980) A brief description of Canadian fisheries for Atlantic bluefin tuna. Col Vol Sci000 Pap. ICCAT 11:93-97

ICCAT (1980) Report of bluefin tuna workshop (Santander, Spain, 3-8 Sept 1979). Col Vol Sci Pap ICCAT 11:1-89. https://www.iccat.int/Documents/CVSP/CV011_1980/CV011000001.pdf

ICCAT (2010) ICCAT manual. Description of species. Chapter 2; 2.1.5 Atlantic bluefin tuna, vol 99. Madrid, ICCAT, pp 93-111. http://iccat.int/Documents/SCRS/Manual/CH2/2_1_5_BFT_ ENG.pdf

Karakulak S (2003) Bluefin tuna fishery in Turkey. In: Workshop on farming, management and conservation of bluefin tuna, 5-7 April 2003. Istanbul, Turkey, Turkish Marine Research Foundation Publication No. 13, pp 120-133

Karakulak S, Oray I, Corriero A, Deflorio M, Santamaria N, Desantis S, De Metrio G (2004) Evidence of a spawning area for the bluefin tuna (Thипnиs thynnus) in the Eastern Mediterranean. J Appl Ichthyol 20:318-320

Kimoto A, Itoh T (2017) Simple update of the standardized bluefin tuna CPUE of Japanese longline fishery in the Atlantic up to 2016 fishing year. Col Vol Sci Pap 73(6):1957-1976

Lebedeff W (1936) Paradise for big game fishing. Tunny, 700 kgs; Swordfish, 180 kgs; Shark, 1800 kgs. Winter season 1935-36 in Turkey. Fish Gaz 113(3102):420-421

Le Gall J (1951) Le thon rouge (Thunnus thynnus L.) dans le Golfe de Gascogne en 1951. Ann Biol Cons Int Expl Mer 8:82-83

Liorzou B, Bigot JL (1993) Actualisation des données sur le thon rouge exploité au large des cotes françaises de Méditerranée. Col Vol Sci Pap ICCAT 40(1):302-306

Logan JM, Rodríguez-Marín E, Goñi N, Barreiro S, Arrizabalaga H, Golet WJ, Lutcavage M (2010) Diet of young Atlantic bluefin tuna (Thunnus thynnus) in eastern and western foraging gound. Mar Biol https://doi.org/10.1007/s00227-010-1543-0, $12 \mathrm{p}$

Lutcavage M, Galuardi B, Lam TCH (2013) Predicting potential Atlantic spawning grounds of western Atlantic bluefin tuna based on electronic tagging results, 2002-2011. Col. Vol. Sci. Pap. ICCAT 69:955-961

MacKenzie BR, Myers RA (2007) The development of the northern European fishery for north Atlantic bluefin tuna (Thuпnиs thynnus) during 1900-1950. Fish Res https://doi.org/10.1016/j. fishres.2007.01.013

Mather III FJ. Distribution and migrations of North Atlantic bluefin tuna. In: Proccedings of the seveth international game fish conference, Galveston, T exas, 15 Nov (1962) 
Mather III FJ, Bartlett MR, Beckett JS (1967) Transatlantic migrations of young bluefin tuna. J Fish Res Bd Canada 24(9):1991-1997

Mather III FJ, Mason Jr JM, Jones AC (1995) Historical document: life history and fisheries of Atlantic bluefin tuna. NOAA technical memorandum, NMFS-SEFSC-370, Miami Fl, 165 p

Medina A, Abascal FJ, Megina C, García A (2002) Stereological assessment of the reproductive status of female Atlantic northern bluefin tuna during migrations to Mediterranean spawning grounds through the Strait of Gibraltar. J Fish Biol 60:203-217. https://doi.org/10.1111/j.10958649.2002.tb02398.x

Neilson J, Campana SE (2008) A validated description of age and growth of Western Atlantic bluefin tuna (Thunnus thynnus). Can J Fish Aquat Sci 65:1523-1527

Ngom Sow F, Ndaw S (2010) Bluefin tuna caught by Spanish baitboat and landed in Dakar in 2010. Col Vol Sci Pap ICCAT 66(2):883-887

Nøttestad L, Tangen $\varnothing$, Sundby S (2009) Norwegian fisheries since the early 1960s: what went wrong and what can we do? Col Vol Sci Pap ICCAT 63:231-232

Pereira J (2012) Historical bluefin tuna catches from southern Portugal traps. Col Vol Sci Pap ICCAT 67:88-105

Piccinetti C (1980) The bluefin seine fishery in the Adriatic. Col Vol Sci Pap ICCAT 11:124-128

Piccinetti C, Di Natale A, Arena P (2013) Eastern bluefin tuna (Thunnus thynnus, L.) reproduction and reproductive areas and season. Col Vol Sci Pap ICCAT 69(2):891-912)

Porch CE (2005) The sustainability of western Atlantic bluefin tuna: a warm blooded fish in a hot blooded fishery. Bull Mar Sci 76:363-384

Rey JC (1980) Description of the longline fishery in the Spanish Mediterranean. Col Vol Sci Pap ICCAT 11:178-179

Richards WJ (1977) A further note on Atlantic bluefin tuna spawning. Col Vol Sci Pap ICCAT 6(2):335-336

Richardson DE, Marancik KE, Guyon JR, Lutcavage ME, Galuardi B, Lam CH, Walsh HJ, Wildes S, Yates DA, Hare JA (2016) Discovery of spawning ground reveals diverse migration strategies in Atlantic bluefin tuna (Thunnus thynnus). PNAS 113(12):3299-3304

Rivas LR (1954) A preliminary report on the spawning of the western North Atlantic bluefin tuna (Thunnus thynnus) in the straits of Florida. Bull Mar Sci Gulf Caribb 4(4):302-322

Rodríguez-Roda J (1964) Biología del atún, Thunnus thynnus (L.), de la costa sudatlántica española. Inv Pesq 25:33-146

Rodríguez-Roda J (1967) Fecundidad de atún, Thunnus thynnus (L.), de la costa sudatlántica española. Inv Pesq 31(1): 33-52

Rodríguez-Roda J (1969) Los atunes jóvenes y el problema de sus capturas masivas. Publicaciones Técnicas de la Junta de Estudios de Pesca. Subsecretaría de la Marina Mercante 8:159-162

Rodríguez-Roda J (1977) Análisis de la población de atunes, Thunnus thynnus (L.), capturados por la almadraba de Barbate (Golfo de Cádiz) durante los años 1963 a 1975. Inv Pesq 41(2):263-273

Rooker J, Alvarado J, Block B, Dewar H, De Metrio G, Prince E, Rodríguez-Marín E, Secor D (2007) Life and stock structure of Atlantic bluefin tuna (Thunnus thynnus). Rev Fish Sci 15:265-310

Rooker J, Arrizabalaga H, Fraile I, Secor DH, Dettman DL, Abid N, Addis P, Deguara S, Karakulak FS, Kimoto A, Sakai O, Macias D, Santos MN (2014) Crossing the line: migratory and homing behaviours of Atlantic bluefin tuna. Mar Ecol Prog Ser 504:265-276

Sakagawa G (1975) The purse-seine fishery for bluefin tuna in the Northwestern Atlantic Ocean. Mar Fish Rev 1126 37(3):8

Santos MN, Rosa D, Coelho R, Lino PR (2016) New observations on the bluefin tuna trap fishery off southern Portugal (NE Atlantic) between 1998-2014: trends on potential catches, catch-at-size and sex ratios. Col Vol Sci Pap ICCAT 72(5):1350-1364

Sarà R (1961) Observations systématiques sur la presence du thon dans les madragues siciliennes. Proc Gen Fish Coun Médit 6:41-61

Sarà G, Sarà R (2007) Feeding habits and trophic levels of bluefin tuna Thunnus thynnus of different size classes in the Mediterranean Sea. J Appl Ichthyol 23(2):122-127 
Scaccini A (1965) Biologia e pesca dei tonni nei mari italiani. Ministero Marina Mercantile, Mem 12:101

Takeuchi Y, Suda A, Suzuki Z (1999) Review of information on large bluefin tuna caught by Japanese longline fishery off Brasil from the late 1950s to the early 1960s. Col Vol Sci Pap ICCAT 49(2):416-428

Takeuchi Y, Oshima K, Suzuki Z (2009) Inference on the nature of Atlantic bluefin tuna off Brazil caught by the Japanese longline fishery around the early 1960s. Col Vol Sci Pap ICCAT 63:186-194

Tangen M (2009) The Norwegian fishery for Atlantic bluefin tuna. Col Vol Sci Pap ICCAT 63:79-93

Tensek S, Pagá García A, Di Natale A (2018) ICCAT GBYP tagging activities in phase 6. Col Vol Sci Pap ICCAT 74(6):2861-2872

Tiews K (1963) Synopsis of biological data on bluefin tuna, Thunnus thynnus (Atlantic and Mediterranean). FAO Fish Rep 6(2):422-481

Zaitsev Y (2003) Bluefin tuna in the Black Sea. In: Workshop on farming, management and conservation of bluefin tuna, 5-7 April 2003. Istanbul, Turkey, Turkish Marine Research Foundation Publication No. 13, pp 118-119

Open Access This chapter is licensed under the terms of the Creative Commons Attribution 4.0 International License (http://creativecommons.org/licenses/by/4.0/), which permits use, sharing, adaptation, distribution and reproduction in any medium or format, as long as you give appropriate credit to the original author(s) and the source, provide a link to the Creative Commons license and indicate if changes were made.

The images or other third party material in this chapter are included in the chapter's Creative Commons license, unless indicated otherwise in a credit line to the material. If material is not included in the chapter's Creative Commons license and your intended use is not permitted by statutory regulation or exceeds the permitted use, you will need to obtain permission directly from the copyright holder.

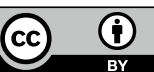

